\title{
MONOGRAF SEBAGAI SALAH SATU CARA PUBLIKASI BUKU DARI HASIL PENELITIAN
}

\author{
Endang Fatmawati \\ Dosen LB Program Studi D4 Informasi dan Humas \\ Sekolah Vokasi, \\ Universitas Diponegoro Semarang \\ Email: eenfat@yahoo.com
}

\begin{abstract}
Abstrak
Arti monograf adalah menulis pada satu subjek. Formulir buku monograf diterbitkan dalam satu volume atau satu seri. Masalah monograf bukan masalah lengkap dalam beberapa volume. Lebih tepatnya bukan masalah radiasi. Buku monograf adalah bentuk langsung dan ringkas dari menulis makalah penelitian dengan rincian tentang subjek tertentu. Menulis monograf didasarkan pada survei literatur, yang berarti itu adalah ekstraksi dan kompilasi informasi yang relevan pada satu topik khusus. Buku monograf adalah karya penelitian yang ditulis oleh seorang ahli atau spesialis di bidangnya dan berisi satu topik atau beberapa mata pelajaran terkait. Monograf disediakan sebagai referensi literatur dan dapat digunakan untuk menyimpan materi pembelajaran. Dosen dan pustakawan memiliki kesempatan untuk membuat buku monograf dari penelitian yang dilakukan. Artikel penelitian yang diterbitkan dalam jurnal dapat dikonversi menjadi buku kategori monografi sehingga secara substansial lebih bernilai, memiliki kepadatan materi yang lebih besar, dan memiliki peluang diseminasi yang lebih besar.

Kata kunci: monografi, pustakawan, penelitian, buku, dosen.
\end{abstract}

\section{Abstract}

The meaning of monograph is writing on a single subject. The monograph book form is published in one volume or one series. A monograph issue is not a complete issue in several volumes. More precisely not a radiant issue. The monograph book is a straightforward and concise form of writing a research paper with details on a particular subject. Writing a monograph is based on a literature survey, meaning it is the extraction and compilation of relevant information on a single specialized topic. A monograph book is a work of research written by an expert or a specialist in its field and contains one topic or some related subjects. The monograph is provided as a literature reference and can be used to hold learning material. The lecturer and librarian have the opportunity to create a monograph book from research done. Research articles published in journals can be converted into monograph category books so that 
they are substantially more valuable, have greater material density, and have greater dissemination opportunities.

Keywords: monograph, librarian, research, book, lecturer. 


\section{Pendahuluan}

Pustakawan yang produktif menulis menjadi katalisator untuk terus memahatkan karya nyata dalam publikasi ilmiah. Bagi pustakawan yang baru belajar menjadi penulis pemula, kebingungan dalam menerbitkan sebuah karya merupakan hal yang wajar. Pustakawan yang selesai melakukan kajian atau penelitian pasti memiliki luaran laporan hasil penelitian. Hasil penelitian tersebut berupa publikasi artikel ilmiah hasil penelitian yang didokumentasikan, kemudian mungkin juga telah diterbitkan di sebuah jurnal ataupun prosiding temu ilmiah.

Jika pustakawan memiliki karya tulis hasil penelitian, maka sebetulnya bisa diolah lagi dan dikemas informasinya menjadi sebuah buku berjenis monograf (monograph). Asumsi saya bahwa sayang sekali jika hasil penelitian ilmiah hanya berhenti didokumentasikan, atau hanya untuk kepentingan pengajuan angka kredit saja. Begitu juga jika hanya selesai didesiminasikan dalam publikasi jurnal. Jika jurnal sudah dalam Open Journal Systems (OJS) maka masih signifikan jangkauan aksesnya, tetapi persoalannya jika jurnal hanya dicetak dalam kalangan terbatas dan belum ada versi online. Bisa dibayangkan bahwa hasil penelitian tersebut tidak cepat penyebarannya dan kurang menjangkau dalam ranah global. Pada dasarnya jika publikasi jurnal maka hanya terbatas formatnya mengikuti ketentuan template jurnal tertentu. Selanjutnya juga singkat dan padat karena artikel jurnal hanya merupakan ringkasan hasil penelitian saja. Namun berbeda cakupannya jika disusun kembali dalam bentuk monograf dengan penambahan teori maupun tinjauan literatur yang relevan membahas topik yang diteliti. Hasilnya menjadi karya penelitian yang ditulis oleh ahli atau spesialisasi di bidangnya dan berisi satu topik atau sejumlah subjek yang berkaitan. 
Dalam pengamatan saya, bahwa kenyataan di lapangan masih jarang laporan hasil kajian pustakawan itu disusun kembali dalam bentuk kemasan buku monograf. Padahal jika ditulis dalam bentuk monograf maka bisa menambah nilai manfaat dari hasil penelitian yang telah dilakukan. Misalnya buku yang diterbitkan oleh penerbit dan dipasarkan online, maka jangkauan penyebarannya menjadi lebih luas. Disamping itu, oleh karena berupa buku maka bisa diajukan untuk angka kredit yang nilai kumnya tergolong cukup besar. Hal ini harusnya menjadi penyemangat dan pemantik bagi pustakawan untuk memulai dan mencobanya. Mungkin menulis monograf bagi sebagian pustakawan masih tergolong awam. Hal ini saya rasa karena belum terbiasa saja. Tulisan ini memberikan pemahaman konseptual bagi pustakawan terkait dengan buku monograf. 


\section{Pembahasan}

\section{Definisi Monograf}

Pustakawan pasti sering mendengar istilah monograf dalam kesehariannya. Bahkan ketika pustakawan mengolah koleksi atau bahan perpustakaan, saya yakin para pustakawan sudah sering menemuinya. Hanya saja mungkin pustakawan yang bersangkutan ketika mengolah monograf, kurang memahami bahwa ternyata bahan pustaka yang diolah tersebut tergolong koleksi dalam kategori monograf.

Kata monograf (monograph) berasal dari bahasa Yunani. Monograf terdiri dari kata "mono" dan "graph". Kata mono artinya tunggal (single), sedangkan graph artinya menulis (writing). Jadi bisa dikatakan monograf adalah menulis pada satu subjek. Monograf merupakan buku yang isi tulisannya tentang satu subbidang ilmu tertentu yang spesifik. Beberapa persoalan yang relevan dengan bahasan monograf, seperti: Apa itu monograf? Bagaimana cara menulis buku monograf? Apa perbedaan antara buku monograf dengan buku lainnya? Apa bedanya dengan publikasi hasil penelitian dalam bentuk artikel jurnal? Lalu bagaimana karakteristik koleksi yang termasuk monograf?

Buku monograf memiliki beberapa karakteristik. Monograf merupakan bentuk singkat dari penulisan laporan penelitian atau makalah hasil penelitian dengan rincian pada subjek tertentu. Artinya buku monograf itu berisi tulisan satu topik tertentu yang dikhususkan untuk hasil penelitian dan memberikan penjelasan pada suatu bidang ilmu saja. Secara umum dalam menulis monograf didasarkan pada survei literatur, artinya merupakan ekstraksi dan kompilasi informasi yang relevan pada satu subjek. Apabila hasil penelitian yang telah dilakukan dapat dikonversi menjadi buku kategori monograf, maka cakupan bahasan di dalam 
bukunya lebih bernilai substantif. Selain memiliki kepadatan materi, juga peluang diseminasi jauh lebih besar.

Selanjutnya secara keseluruhan buku monograf dapat memberikan informasi yang bernilai tentang suatu topik. Isi bukunya menyajikan satu topik bahasan pada bidang ilmu tertentu. Monograf berbeda dengan terbitan berseri yang lengkap dalam satu volume atau sejumlah volume tertentu. Buku monograf merupakan buku ilmiah yang dikemas dalam bentuk buku dengan bentuk penulisan yang diterbitkan dalam satu jilid atau seri dan menjadi buah dari pemikiran penelitinya.

Monograf merupakan terbitan tunggal yang selesai dalam satu jilid dan tidak berkelanjutan. Buku monograf memiliki substansi tema yang lebih spesifik, hanya membahas satu tema atau satu topik saja dalam satu bahasan buku. Dalam konteks ini, pustakawan yang meneliti berarti berperan sebagai peneliti dan ketika membuat monograf maka berperan sebagai penulis monograf. Idealnya buku monograf ditulis oleh penulis tunggal dan bukan berbentuk kompilasi berbagai tulisan.

Dalam sitasi (citation) adanya co-authorship memang telah terbukti memiliki dampak kutipan yang lebih tinggi dalam banyak kasus publikasi ilmiah. Banyak penelitian telah menunjukkan bahwa berbagai jenis kolaborasi memiliki efek luar biasa terkait dengan kutipan. Kondisi ini dipercaya secara luas bahwa kolaborasi memang menguntungkan dalam sains. Misalnya dengan artikel yang ditulis secara kolaboratif antar disiplin ilmu, maka cenderung menarik lebih banyak kutipan daripada artikel tunggal. Hal yang sama juga berlaku untuk penelitian yang menghasilkan buku monograf.

Hasil penelitian yang dilakukan oleh Thelwall and Sud (2014) yang menguji apakah monograf ilmiah yang ditulis bersama itu memiliki lebih banyak kutipan daripada monograf tunggal, dengan 
menggunakan buku yang diterbitkan sebelum tahun 2011 dari 30 kategori di Web of Science. Hasilnya menunjukkan bahwa monograf tunggal ternyata mendominasi daripada monograf kolaboratif. Namun demikian, tidak memberikan bukti keunggulan kutipan pada monograf kolaborasi. Akibatnya bagi penyandang dana dan manajer penelitian mendorong kolaborasi dalam sains untuk menghasilkan penelitian berkualitas tinggi, kemudian tidak boleh memberi insentif pada penelitian kolaboratif dalam subjek berbasis buku atau dalam penelitian yang bertujuan untuk menghasilkan monograf. Dalam konteks ini, para peneliti sendiri secara bebas yang memutuskan apakah akan berkolaborasi atau tidak. Kolaborasi tidak penting untuk buku monograf ilmiah di setiap bidang ilmu, meskipun dampaknya terkait dengan jumlah kutipan yang lebih tinggi.

Namun dalam praktiknya, saya jumpai ada buku monograf yang ditulis lebih dari satu orang. Hal ini berarti semua anggota tim peneliti adalah sebagai penulis buku monograf. Campbell, Ed Pentz, Borthwick (2012: 115) menjelaskan bahwa setiap penerbit menggunakan istilah monograf dengan cara yang sedikit berbeda, tetapi secara umum bahwa monograf telah menjadi istilah umum untuk semua buku yang bukan dari jenis referensi, yang merupakan bahan utama, dan mungkin penulisnya banyak, penulis tunggal, maupun koleksi yang sudah diedit.

Secara kapabilitas dan kapasitas, buku monograf lekat dengan profesi dosen. Namun sekalipun monograf lebih dekat dengan dosen, dari hasil observasi partisipatif yang saya lakukan, diperoleh gambaran bahwa belum semua dosen itu mengerti dan memahami dengan baik cara membuat dan menyusun draft buku monograf. Bahkan sering dijumpai kategori buku yang sudah selesai dibuat, tetapi substansinya setelah dilakukan penilaian ternyata hasilnya kurang layak atau tidak sesuai dengan 
karakteristik jenis bukunya. Sebagai contoh prakata dari penulis disampaikan buku monograf tetapi setelah dicermati reviewer ternyata justru tergolong buku ajar saja. Kondisi seperti ini biasa terjadi dalam penilaian angka kredit.

Contoh persoalan lainnya, ada dosen yang membuat buku monograf tetapi justru jadinya tergolong buku referensi, atau sebaliknya membuat buku referensi malah jadinya justru buku ajar. Selanjutnya di dalam pembahasannya juga belum merujuk pada publikasi riset yang terkait dengan topik penelitian yang pernah dilakukan, sehingga dalam daftar pustaka tidak tercantum rujukan hasil penelitian lainnya, maupun sumber pustaka lain yang dimilikinya.

Oleh karena monograf merupakan hasil karya tulis yang ditulis oleh seorang ahli atau spesialisasi pada bidang ilmu tertentu, maka monograf merupakan bentuk tulisan tentang subbidang ilmu yang spesifik. Untuk memudahkan pemahaman, saya ilustrasikan misalnya pustakawan melakukan kajian atau penelitian dalam cabang ilmu tentang "Analisis Pengolahan Bahan Perpustakaan di Perpustakaan X". Laporan kajian tentang pengolahan bahan perpustakaan tersebut dapat dibuat monograf dengan hanya fokus mengambil salah satu subbidang dalam pengolahan bahan perpustakaan. Cakupan subbidang ilmunya, antara lain: Pengolahan Jurnal, Pengolahan Tugas Akhir, Pengolahan Majalah, Pengolahan Surat Kabar, Sistem Pengolahan Koleksi, dan lain sebagainya.

Selanjutnya jika pustakawan ingin menyusun topik tersebut dalam bentuk monograf, maka hanya membahas sebagian kecil saja dari bahasan, misalnya "Pengolahan Majalah". Artinya ketika dibuat monograf maka bahasan isi buku terlihat jauh lebih spesifik atau hanya membahas "salah satu aspek dari satu bidang ilmu" tentang bagaimana mengolah majalah saja. Lalu sistematika 
bahasan di dalam buku monografnya bisa difokuskan pada uraian definisi majalah, subyek majalah, artikel majalah, inventaris majalah, penerbit majalah, jenis majalah, metode menginventaris majalah, dan bahasan lain yang relevan dengan pengolahan majalah.

\section{Aspek Monograf}

Satu hal yang perlu diingat bahwa hasil penelitian yang sudah dipublikasikan dalam bentuk artikel jurnal dan sudah diterbitkan, maka sumber artikel jurnal tersebut dapat dijadikan bahan atau referensi dalam menulis monograf. Selanjutnya dalam menerbitkan buku monograf harus jeli memilih penerbit yang profesional. Hal ini sangat penting, karena dalam perjalanannya ketika buku yang ditulis terjual maka penulis akan mendapatkan royalti dari hasil penjualan buku.

Kini banyak sekali variasi penerbit dari yang komersial, mayor, indie (independent), sampai self publishing. Hal terpenting ketika menerbitkan buku monograf adalah memilih penerbit yang bereputasi baik, profesional, proses pelayanannya cepat, kredibel, memiliki visi misi yang jelas, fleksibel, memiliki jaringan pemasaran, serta jujur dalam melaporkan hasil penjualan maupun dalam memberikan royalti. Oleh karena syarat publikasi monograf harus diterbitkan dan disebarkan, maka harus diterbitkan di penerbit yang memiliki ISBN.

Hal-hal substantif yang perlu diperhatikan dalam membuat buku monograf, antara lain: memahami karakteristik buku, struktur buku, segmentasi buku, alur dan struktur, serta menggunakan bahasa tulis formal. Biasanya penulis buku monograf akan memperoleh sertifikat sebagai penulis buku dan dalam penjualannya akan dibantu dalam memasarkan buku yang diterbitkan. 
Sitasi wajib disertakan apabila merujuk atau meminjam pemikiran orang lain. Untuk kutipan bisa dicantumkan dalam bentuk catatan kaki (footnote), kutipan langsung, maupun kutipan tidak langsung. Kepiawaian untuk interpretasi, analisis, dan parafrase perlu dilakukan ketika mengedit draft monograf. Langkah terakhir adalah mengecek dengan bantuan aplikasi antiplagiarisme untuk mengetahui tingkat kemiripan karya tulis yang nantinya dibukukan menjadi monograf.

Untuk menyusun buku monograf secara utuh, pada bagian metodologi tidak harus dipisah menjadi bab tersendiri, tetapi bisa dimasukkan secara implisit pada tinjauan pustaka atau pembahasan. Penyampaian untuk landasan teori maupun tinjauan pustaka dapat ditulis dengan cara memaparkan teori para tokoh yang ahli di bidangnya. Isi buku monograf adalah terstruktur, sehingga memiliki alur dan struktur sesuai dengan alur logika dan urutan atau peta keilmuan yang dimiliki penulisnya.

Monograf penelitian (research monographs) menyajikan hasilhasil penelitian asli. Gaya penulisan monograf dari hasil penelitian dikemas dengan lebih padat, lebih lengkap, fokus mendeskripsikan topik yang diangkat, membicarakan tetap satu bidang ilmu, serta tidak melebar ke topik lainnya yang tidak relevan. Dalam www.lisbdnet.com disebutkan bahwa monograf penelitian merupakan laporan yang diterbitkan secara terpisah tentang penelitian asli yang terlalu panjang (too long), terlalu terspesialisasi (too specialized), atau tidak cocok untuk dipublikasikan di salah satu jurnal standar.

Bagaimana etika publikasinya jika penelitian dilakukan secara tim? Hal ini tidak menjadi persoalan dengan catatan mendapatkan persetujuan dari anggota tim peneliti lainnya. Justru yang seringkali ada temuan di lapangan bahwa ada penelitian yang 
dilakukan murni oleh mahasiswanya namun diklaim sebagai penelitian dari Dosen untuk kenaikan pangkat atau jabatan fungsional Dosen yang bersangkutan. Ada juga temuan bahwa penelitian tertentu yang telah dilakukan oleh pustakawan A, tetapi dibajak dan diplagiasi menjadi penelitiannya pustakawan B. Dalam konteks ini, tentu dibutuhkan kejujuran, kesadaran moral, dan integritas personal.

\section{Tampilan Monograf}

Dalam membuat monograf bahwa pada halaman awal perlu diberi halaman prakata (preface) dan kata pengantar (foreword). Perbedaan keduanya adalah jika prakata merupakan pengantar dari penulisnya sendiri, sedangkan jika kata pengantar merupakan pengantar dari orang lain terhadap penulis buku monograf tersebut. Tujuan penelitian lebih baik jika dicantumkan pada prakata yang dibuat di halaman awal.

Selanjutnya isi monograf harus memenuhi kaidah penulisan sesuai format penelitian ilmiah yang utuh. Mengenai bagaimana struktur kontennya, seperti halnya jumlah subbab dan yang lainnya, maka monograf secara umum paling tidak terdiri dari: cover, pendahuluan, landasan teori, tinjauan pustaka, hasil dan pembahasan, kesimpulan, serta daftar pustaka.

Cover berisi judul, nama penulis, nama penerbit yang menerbitkan buku monograf. Cover buku monograf harus didesain semenarik mungkin. Apa yang nampak pada halaman awal cover menjadi kesan pertama bagaimana buku monograf itu dipersepsikan oleh pembaca. Jika tidak ada sinopsis buku di cover belakang, biasanya orang akan membaca secara singkat daftar isi yang ada di halaman awal untuk mengetahui sekilas isi bukunya.

Jika judul monografnya "Pengolahan Jurnal" maka subjudulnya bisa langsung membahas terkait definisi, jenis jurnal, 
inventaris jurnal, indeks artikel jurnal, dan seterusnya. Untuk metodologi penelitian, bisa dimasukkan secara implisit dalam tinjauan pustaka atau pada bagian pembahasan. Hal yang terpenting bahwa judul monograf dibuat yang spesifik dan menarik serta menggambarkan isi naskah atau substansi naskah. Hindari topik penelitian yang terlalu luas, sudah banyak dibahas, dan tidak relevan dengan perkembangan keilmuan. Strategi untuk memunculkan ide topik penelitian, misalnya dengan mencari publikasi terkini, mengidentifikasi permasalahan yang dikumpulkan, mencari informasi isu-isu penelitian terbaru, mengumpulkan gagasan topik, maupun mencari tinjaun pustaka penelitian terdahulu.

Pendahuluan berisi latar belakang, rumusan masalah yang mengandung nilai kebaharuan, tujuan, dan metodologi pemecahan masalah. Bagian pendahuluan sangat menentukan penilaian struktur konten monograf pada halaman berikutnya. Artinya pada bagian awal harus dibuat semenarik mungkin untuk mempersuasif pembaca. Bagian pendahuluan monograf harus mencerminkan urgensi kajian dan pokok permasalahan yang akan dibahas. Namun bukan berarti bagian lainnya setelah pendahuluan tidak diperhatikan. Tentu ada hal-hal lain yang wajib diperhatikan agar isi monograf sampai dengan bagian kesimpulan menjadi bagian yang komprehensif satu kesatuan yang mudah dipahami pembaca.

Landasan teori mengupas berbagai teori yang digunakan sebagai pisau analisis penelitian secara lengkap dan jelas. Untuk bagian tinjauan pustaka, bisa langsung ditulis tentang topik yang dibahas. Hal ini didukung dengan data dan penelitian terdahulu, sehingga nampak posisi atau celah dari penelitian yang dilakukan.

Untuk menjawab permasalahan yang sudah dirumuskan adalah dengan melakukan penelitian berkaitan dengan fenomena 
yang sedang diteliti menggunakan metode penelitian yang tepat. Lalu data dianalisis secara mendalam menggunakan landasan teori dan menjelaskan dari literatur yang diacu. Hasil dan pembahasan harus fokus menjawab rumusan permasalahan. Analisis hasil penelitian dijelaskan dengan model analisis sesuai dengan tata bahasa ilmiah. Paling tidak seperti artikel ilmiah hasil penelitian pada jurnal nasional terakreditasi Science and Technology Index (SINTA).

Hasil dan pembahasan dibuat dalam satu subpokok bahasan. Agar monograf berkualitas dan mendapatkan hasil maksimal dalam penilaian oleh tim penilai angka kredit, maka dalam bagian 'hasil dan pembahasan' diusahakan menyertakan sekurangkurangnya $70 \%$ dari sumber pustaka yang dirujuk. Selain itu, agar lebih jelas bahasannya maka pada bagian pembahasan juga sebaiknya disertai tabel, ilustrasi gambar, atau bagan yang mendukung dengan mencantumkan sumbernya. Ilustrasi yang ada tulisannya, maka dibuat jangan terlalu kecil agar pesan dapat dibaca dengan jelas oleh pembaca. Selanjutnya bagian akhir kesimpulan harus fokus mencerminkan hasil pembahasan dan menjawab rumusan masalah.

Agar terhindar dari unsur plagiasi karya ilmiah dan sesuai etika penulisan, jika mengutip dari karya orang lain, maka harus menuliskan sumbernya selengkap mungkin dalam daftar pustaka. Cara menulis daftar pustaka monograf bisa dibuat daftar pustaka di tiap bab untuk memperkuat bahasan atau jadi satu secara keseluruhan di bagian belakang. Agar lebih up to date dan memperkuat bahasan maka sumber rujukan sebaiknya diperbanyak dari sumber primer (jurnal) bukan dari buku.

Pada saat menuliskan sumber rujukan dalam daftar pustaka maka harus diperhatikan teknis penulisannya. Artinya daftar pustaka harus lebih diperhatikan agar tidak banyak kesalahan. 
Untuk menghindari kesalahan dalam sitasi dan agar konsisten dalam menggunakan gaya penulisan daftar pustaka, maka sebaiknya menggunakan aplikasi reference management tools, seperti: mendeley, endnote, zotero, refworks, atau yang lainnya. Oleh karena monograf diharapkan menjadi rujukan ilmiah dalam penelitian, maka sebaiknya tidak mengutip yang sumbernya dari situs blog, wikipedia, maupun sumber informasi lainnya yang kurang kredibel.

Cara membuat buku monograf itu berbeda dengan ketika membuat buku ajar maupun buku referensi. Begitu juga sangat berbeda caranya dengan membuat artikel pada jurnal. Dari istilahnya saja sudah berbeda antara "artikel jurnal" dan "buku". Misalnya jumlah halaman artikel ilmiah pada jurnal hanya terbatas, sedangkan jumlah halaman buku monograf jauh lebih banyak. Selanjutnya dalam membuat tinjauan pustaka untuk sebuah monograf, boleh mengutip semua artikel penulis yang topiknya berkaitan dengan topik yang dibahas dalam monograf.

Untuk efisiensi pengeditan, maka sebelum diterbitkan dan dicetak, draft naskah monograf harus dibaca berulang-ulang dengan lebih cermat dan teliti. Apabila diperlukan maka membutuhkan bantuan orang lain untuk membacanya. Hal ini untuk menghindari kesalahan redaksional, salah ketik, tata penulisan, pemakaian tanda baca, ejaan, diksi, spasi, kutipan, kesalahan pada saat proses mengetik (typo), kalimat tidak berbunyi, tanda baca, kalimat tidak efektif, tidak adanya koherensi antar paragraf, dan lain sebagainya. Hal-hal lainnya yang perlu diperhatikan ketika menulis isi buku monograf, misalnya: jangan menggunakan ragam bahasa tutur, menggunakan bahasa tulis ilmiah, menggunakan kata baku, memperhatikan kaidah ilmiah, memperhatikan tanda baca, serta sesuai dengan Pedoman Umum Ejaan Bahasa Indonesia (PUEBI). 


\section{Contoh Akses Monograf}

Sebagai contoh terbitan monograf, bahwa Perpustakaan Nasional RI menyediakan banyak sekali judul-judul buku monograf. Pemustaka dari manapun berada yang membutuhkan sumber informasi tentang koleksi-koleksi monograf bisa mengakses melalui https://www.perpusnas.go.id/collections.php?lang=id\&id=Monogra f. Dalam menu "cari" misalnya ketik "Babad Dipanegara", maka muncul seperti tampilan berikut:

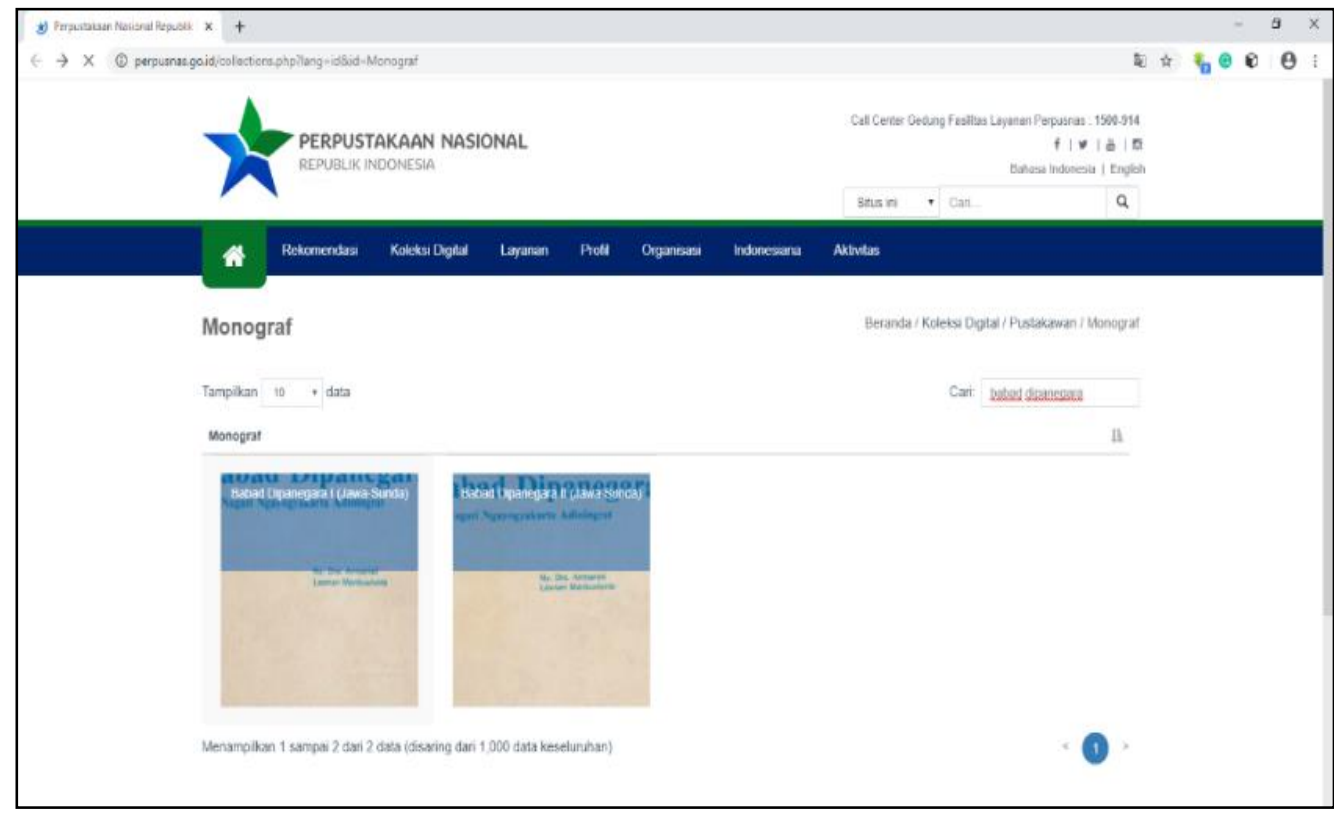

Sebagai informasi bahwa di Perpustakaan Nasional RI ada bagian khusus yang menangani koleksi yang tergolong monograf yaitu kelompok pengolahan bahan pustaka monograf, dan saat ini dijabat atau dipimpin oleh Ibu Dra. Fathmi, SS (Pustakawan Utama Perpusnas RI). Tugas kelompok pengolahan bahan pustaka monograf di Perpusnas RI, antara lain:

1. Membantu menyusun perencanaan pengolahan bahan pustaka monografi seperti: buku, naskah kuno/manuskrip, phamflet, 
brosur, buklet, grey literature, kliping, laporan, poster, serta referens;

2. Mendata, melakukan verifikasi, membuat katalogisasi, tajuk subjek koleksi monografi dan memasukkan data bibliografis dalam pangkalan data;

3. Mencatat penambahan tajuk utama dan/atau perubahan klasifikasi yang telah disepakati untuk diserahkan kepada kelompok tajuk otoritas;

4. Melakukan kerjasama dan koordinasi dengan kelompok lain atau unit kerja lain;

5. Melakukan bimbingan dan konsultasi dalam pengolahan bahan pustaka monografi.

Monograf termasuk kategori buku karena memiliki ISBN dan diterbitkan oleh penerbit. Dalam https://isbn.perpusnas.go.id/ disebutkan bahwa ISBN merupakan deretan angka 13 digit sebagai pemberi identifikasi unik secara internasional terhadap satu buku maupun produk seperti buku yang diterbitkan oleh penerbit. Semua informasi buku (judul, penulis, penerbit, tahun terbit) tercantum dalam ISBN.

Satu buku monograf hanya mempunyai satu ISBN, kemudian ISBN buku yang satu berbeda dengan buku monograf yang lainnya. Setiap nomor memberikan identifikasi unik untuk setiap terbitan buku monograf dari setiap penerbit, sehingga dengan keunikan tersebut memungkinkan pemasaran produk yang lebih efisien bagi penerbit, toko buku, perpustakaan, universitas, maupun distributor.

Perpustakaan Nasional RI merupakan Badan Nasional ISBN yang berhak memberikan Katalog Dalam Terbitan (KDT) dan ISBN kepada penerbit yang berada di wilayah Indonesia. Saat ini proses pendaftaran penerbit, permintaan ISBN dan KDT telah dibuat 
lebih mudah dengan layanan satu pintu, sehingga sekali informasi judul terbitan diserahkan maka menjadi bagian dari pangkalan data bibliografi. Dalam proses selanjutnya akan muncul pada terbitan KDT di Perpusnas RI, dan memungkinkan perpustakaan maupun toko buku yang mencari terbitan untuk dibeli, dapat mengetahui informasi terbitan buku terbaru.

\section{Publikasi Buku}

Publikasi berarti merujuk suatu tindakan untuk menerbitkan, sehingga mempublikasikan buku monograf artinya bagaimana membuat isi monograf tersebut dapat digunakan atau diakses oleh masyarakat luas. Cara mempublikasikan dapat dilakukan dengan melalui unggah (upload) ke repositori institusi, dicetak melalui penerbit profesional, atau melalui sistem digital library.

Glogoff and Bailey (2019) mengulas sifat dan jenis monograf yang digunakan dalam perpustakaan sains dan teknologi dalam buku yang pertama kali diterbitkan tahun 1983. Buku dikhususkan untuk mempertimbangkan kontribusi monograf untuk semua jenis perpustakaan sains-teknologi serta kemungkinan perannya di masa depan. Beberapa topik terkait yang disertakan, seperti sumber untuk memperoleh monograf, alat yang digunakan untuk memilihnya, dan sikap penerbit terhadap kreasi mereka. Jenis-jenis karya monograf yang dibahas adalah: buku dan buku teks, buku pegangan, ensiklopedi dan kamus, dokumen pemerintah dan laporan teknis, paten, ulasan paten dan kompilasi tabel, notebook laboratorium, laporan kemajuan, disertasi, katalog pabrik dan direktori pabrik, serta direktori serial baru (new serial directories).

Era digital ibarat informasi ada di ujung jari. Contoh direktori Harrod's Librarians' Glossary and Reference Book (Prytherch, 2016) dalam versi eBook telah menjadi referensi yang lebih cepat 
untuk menjelaskan istilah spesialis, jargon dan akronim, menemukan URL, baik perpustakaan berbasis cetak atau digital, pengarsipan, manajemen arsip, konservasi, penjualan buku, atau penerbitan. Pada edisi kesepuluh, terminologi web, URL, dan istilah TI telah diperbarui. Selanjutnya cakupan istilah yang terkait dengan digitalisasi dan sumber daya digital, portal, multimedia, dan produk elektronik juga telah diperluas. Direktori Harrod's Glossary kini mencakup segala sesuatu mulai dari istilah pencetakan tradisional hingga mesin pencari dan dari format buku hingga URL, ketentuan manajemen pengetahuan, perkembangan di bidang kekayaan intelektual, hak cipta, paten, privasi, maupun pembajakan. Entri dimasukkan pada klasifikasi dan pengkodean file, manajemen arsip dan pengarsipan, maupun aspek perpustakaan dan keterampilan informasi yang terbaru.

Untuk penerbitan karya ilmiah yang dipublikasikan atau publikasi ilmiah yang berupa buku, meliputi 3 (tiga) kategori, yaitu: buku ajar, buku referensi, dan buku monograf. Karakteristik ketiganya memiliki persamaan bahwa penerbitan buku dapat disebarluaskan, diedarkan, atau dipublikasikan sesuai keinginan. Selanjutnya buku ditulis secara ilmiah atau mengikuti kaidah penulisan ilmiah, memiliki International Standard Book Number (ISBN), editor buku bereputasi, isi dari buku secara keseluruhan tidak menyimpang dari Pancasila dan UUD 1945, berukuran folio $15 \times 23 \mathrm{~cm}(\mathrm{~F} 4)$ dengan spasi 1.15, jumlah halaman minimal dengan tebal minimal 40 halaman (format UNESCO), serta memiliki batas kepatutan 1 buku pertahun.

Secara lebih khusus untuk membedakan bahwa buku yang disusun adalah termasuk buku monograf, karakteristiknya antara lain: 
1. Secara substantif hanya membahas satu aspek dalam satu bidang ilmu saja;

2. Dari sisi sumber pembuatannya, berasal dari hasil penelitian atau riset sehingga ruang lingkup penggunaan bukunya dapat digunakan untuk penelitian, pengajaran, pegangan kuliah, maupun materi pembelajaran;

3. Isi bahasannya sesuai alur logika, ada urutan keilmuannya, dan memiliki peta penelitian;

4. Gaya penyajiannya berbentuk formal dengan bahasa ilmiah dengan aspek pembelajaran yang menggunakan metode terbimbing;

5. Sumber publikasi lain yang dimiliki (hasil penelitian dan publikasi jurnal) yang relevan dengan topik monograf, harus dirujuk dalam isi buku dan dicantumkan sumbernya dalam daftar pustaka.

Dalam katalogisasi perpustakaan, monograf memiliki makna yang lebih luas, yaitu publikasi dalam satu volume. Sebetulnya istilah buku monograf untuk membedakan antara terbitan berseri atau tidak. Terbitan buku monograf adalah tunggal atau tidak ada seri selanjutnya. Jadi berbeda dengan publikasi serial seperti: majalah, buletin, jurnal, tabloid, maupun koran/surat kabar.

Buku monograf merupakan tulisan ilmiah dalam bentuk buku, yang merupakan hasil karya tulis seorang pakar subyek (specialist) tertentu, substansi pembahasannya hanya pada satu topik dalam satu bidang ilmu tertentu atau salah satu aspek dari sebuah subyek. Sementara itu, buku referensi merupakan buku yang substansi pembahasannya hanya pada satu bidang ilmu kompetensi penulis, berisi topik atau tema yang cukup luas, serta memuat kumpulan fakta informasi ringkas dan padat terkait dalam satu bidang ilmu pengetahuan. 
Selain ditulis mandiri, buku kategori referensi bisa disusun dengan sejumlah tim penulis sebagai kontributor maupun editor yang mengedit naskah. Persamaan sumber bahan tulisan untuk buku monograf dan buku referensi adalah sama-sama dari hasil penelitian. Perbedaannya jika buku monograf jumlah terbitannya satu volume, namun jika buku referensi adalah secara periodikal. Selain itu, dari aspek luas bahan tulisannya, jika buku monograf satu aspek dari satu bidang ilmu, sedangkan buku referensi adalah satu bidang ilmu.

Selanjutnya buku ajar merupakan buku yang disusun oleh pengajar yang isinya ditujukan untuk membantu mahasiswa dalam proses pembelajaran ketika mengikuti perkuliahan. Buku ajar termasuk dalam instrumen pembelajaran, disamping buku pegangan, buku teks, buku panduan, maupun buku pedoman.

Buku monograf berbeda dengan buku referensi dan buku ajar. Agar lebih jelas karakteristik ketiganya, dapat saya abstraksikan seperti pada tabel berikut:

\begin{tabular}{|c|c|c|}
\hline B & isi & jar \\
\hline $\begin{array}{l}\text { a. Digunakan untuk } \\
\text { membedakan } \\
\text { dengan terbitan } \\
\text { berseri sehingga } \\
\text { hanya terbit } \\
\text { satu jilid tidak } \\
\text { berkelanjutan. } \\
\text { b. Berisi satu topik } \\
\text { atau beberapa } \\
\text { topik yang saling } \\
\text { berkaitan dalam } \\
\text { satu bidang ilmu. }\end{array}$ & $\begin{array}{l}\text { a. Titik berat } \\
\text { penulisan lebih } \\
\text { kepada jumlah } \\
\text { data dan referensi } \\
\text { data secara } \\
\text { komprehensif. } \\
\text { b. Jangkauan } \\
\text { pembaca lebih luas } \\
\text { karena dapat } \\
\text { dipergunakan oleh } \\
\text { banyak orang. } \\
\text { c. Tidak harus }\end{array}$ & $\begin{array}{l}\text { a. Dibuat oleh pakar di } \\
\text { bidangnya, bisa } \\
\text { ditulis secara } \\
\text { berkelompok. } \\
\text { b. Biasanya terdapat } \\
\text { insentif penyusunan } \\
\text { buku ajar dari } \\
\text { instansi. } \\
\text { c. Hasil dari sebuah } \\
\text { pemikiran tentang } \\
\text { sesuatu atau kajian } \\
\text { bidang tertentu. }\end{array}$ \\
\hline
\end{tabular}




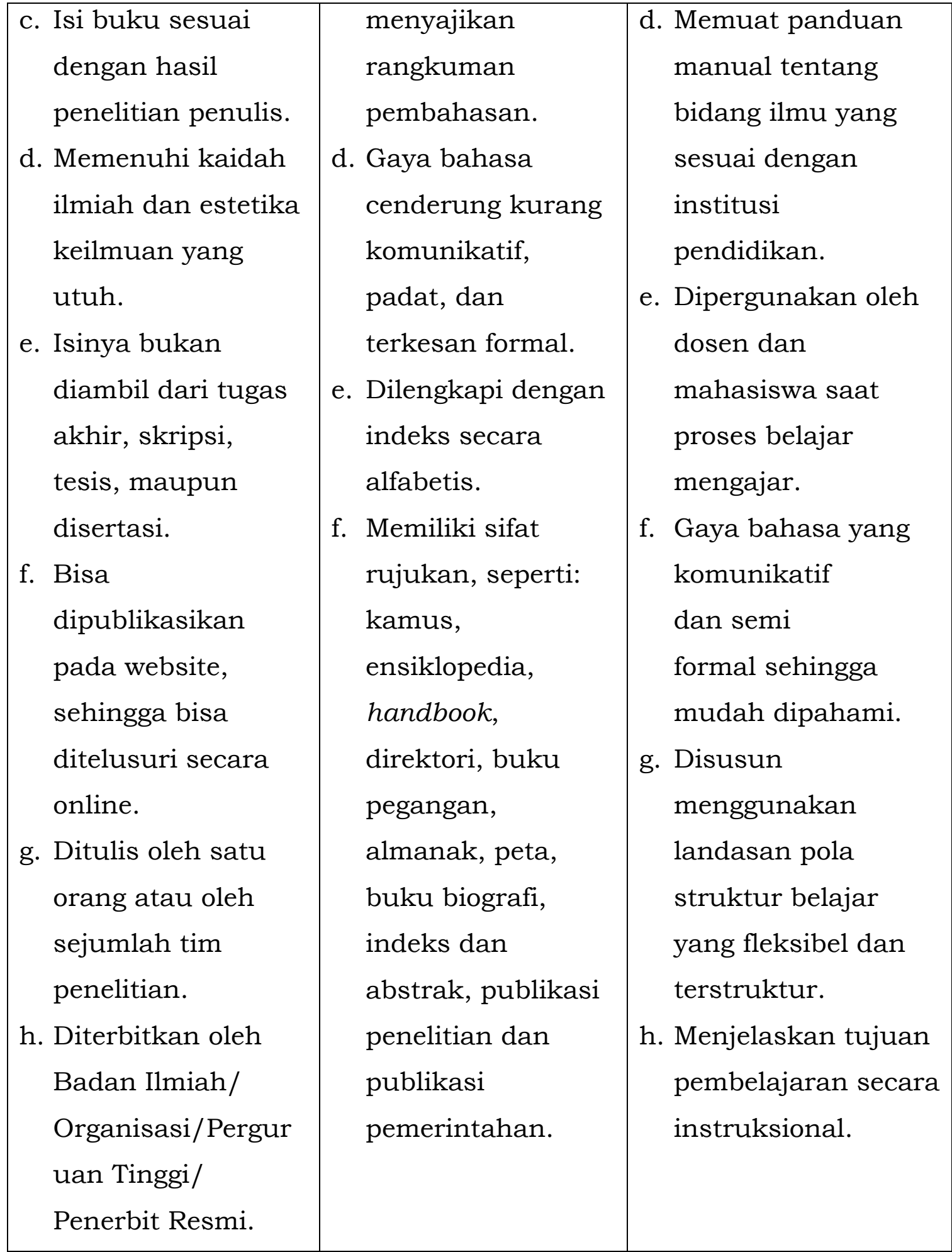

\section{Monograf dan Angka Kredit}

Sejauh ini publikasi ilmiah dalam bentuk buku monograf masih tergolong minim apabila dibandingkan dengan publikasi 
ilmiah melalui jurnal. Dari hasil wawancara dengan beberapa kolega dosen, walaupun segmentasi pembuatan buku monograf lebih pas dengan profesi mereka tetapi kenyataannya belum sepenuhnya disadari dan dilakukan dengan baik. Hal ini karena faktor kesibukan rutinitas mengajar yang super padat, jadwal penelitian yang menyita banyak waktu dan tenaga, jadwal pembimbingan, maupun kesibukan akademik lainnya yang terkait dengan pengabdian masyarakat. Padahal jika diresapi lebih dalam bahwa pembuatan monograf itu menjadi salah satu tips cepat naik pangkat atau jabatan.

Banyak dijumpai pejabat fungsional (misalnya: dosen, pustakawan) yang sudah saatnya naik pangkat atau jabatan, tetapi oleh karena jumlah angka kredit yang dicapai belum memenuhi, maka akhirnya proses kenaikannya menjadi tertunda. Salah satu faktor internal yang menjadi penyebabnya adalah masih rendahnya minat terhadap penelitian, kurangnya motivasi menulis karya ilmiah, dan minimnya publikasi. Parah lagi, aneh tapi nyata, masih saya temui ada dosen yang belum mengerti bagaimana cara membuat buku monograf. Padahal pada dasarnya mereka memiliki modal kepakaran dan keilmuan yang mumpuni.

Fenomena lainnya, contoh kasus ada juga dosen yang jarang menulis artikel ilmiah hasil penelitian, sehingga nihil publikasi di jurnal ilmiah nasional terakreditasi maupun jurnal internasional bereputasi. Jika direnungkan sebetulnya dosen yang sudah memiliki artikel karya tulis ilmiah hasil penelitian yang terbit di jurnal, maka akan sangat mudah bagi dosen tersebut untuk menyusun kembali dengan menjadikan buku monograf. Hal ini karena artikel jurnal yang sudah dipublikasikan dapat dijadikan salah satu bahan atau referensi dalam menulis buku monograf.

Dosen dan pustakawan merupakan contoh jabatan fungsional tertentu. Dalam jabatan fungsional memberikan petunjuk teknis 
tentang kegiatan pengembangan profesi melalui karya nyata dalam bentuk karya tulis. Segala fenomena sosial yang terjadi dalam lingkup kegiatan perpustakaan menarik untuk diteliti. Hal ini berdasar acuan munculnya sebuah masalah yang ditandai dengan adanya kesenjangan antara apa yang seharusnya (das sollen) dengan apa yang menjadi kenyataan (das sein). Kedua hal ini menjadi filosofi dasar yang menjadi alasan ilmiah mengapa sebuah penelitian layak dilakukan. Persoalan klasik biasanya identifikasi masalah penelitian belum fokus dan belum jelas, sehingga belum bisa dirumuskan masalahnya.

Terkait dengan karya berupa buku monograf, bahwa membuat buku monograf bermanfaat secara keilmuwan, akademis, dan sebagai cara untuk mempublikasikan karya ilmiah. Buku monograf menjadi rujukan keilmuan. Dalam perspektif komunikasi ilmiah bahwa dengan produkif melakukan penelitian, maka semakin membuka peluang untuk membuat buku monograf dengan berbagai variasi judul. Secara keilmuan, pustakawan dapat melakukan kajian keilmuwan sesuai bidang yang digelutinya. Manfaat akademis sangat jelas untuk mendukung pembelajaran, menambah literatur, memberi gambaran landasan teori, memudahkan mencari tinjauan pustaka, maupun sebagai bahan diskusi lebih lanjut dalam memahami sebuah topik penelitian.

Sejauh dari peraturan yang saat ini masih berlaku, bahwa bagi dosen, monograf memiliki angka kumulatif yang lumayan tinggi yaitu berkisar antara 20 sampai dengan 25 poin. Nilai angka kredit monograf tersebut lebih tinggi atau lebih besar jika dibanding dengan artikel yang diterbitkan pada jurnal tidak terakreditasi yang nilai angka kreditnya hanya 10 AK saja. Untuk pustakawan sebesar 12,5 AK yang bisa dikategorikan dalam kegiatan membuat karya tulis/karya ilmiah hasil penelitian, 
pengkajian, survei, dan evaluasi di bidang kepustakawanan yang dipublikasikan dalam bentuk buku yang diterbitkan dan diedarkan secara nasional.

Pustakawan tingkat ahli memiliki potensi besar untuk melakukan kajian atau penelitian, baik yang bersifat sederhana maupun kompleks. Hasil kajiannya sangat berpotensi untuk bisa disusun sebagai buku monograf, sehingga hasil kajian atau penelitian yang telah dilakukan dapat berkontribusi lebih dalam untuk memberikan dampak manfaat bagi pengembangan atau kemajuan pada Ilmu Pengetahuan dan Teknologi (IPTEK). Apalagi jika orisinalitas atau keaslian ide tulisan naskah penelitian tergolong sangat tinggi. Begitu juga keterbaruan isu tulisan naskah yang sangat relevan dengan kondisi dalam konteks keilmuan perpustakaan saat ini.

Kegiatan melakukan kajian yang dilakukan tersebut termasuk ke dalam tugas pokok pustakawan keahlian. Tepatnya pada kegiatan unsur utama dalam kegiatan "Pengembangan Sistem Kepustakawanan" dengan subkegiatan yaitu "Pengkajian Kepustakawanan". Pengkajian perlu diagendakan secara rutin dengan tujuan untuk pengambilan keputusan dalam memecahkan masalah dan meningkatkan kinerja pustakawan dan perpustakaan, serta menjadi dasar dalam rangka pengembangan keilmuan perpustakaan. Butir kegiatannya bisa beragam seperti melakukan pengkajian kepustakawanan yang bersifat sederhana (teknis operasional, taktis operasional) dan bersifat kompleks (strategis sektoral, strategis nasional). 


\section{Penutup}

Jenis media publikasi hasil penelitian bisa berupa jurnal dalam bentuk artikel ilmiah hasil penelitian, buku referensi, maupun buku monograf. Publikasi karya ilmiah melalui buku monograf menjadi pertanggungjawaban moral dari hasil penelitian. Harapannya bahwa informasi dan temuan penelitian terbaru yang dikemas dalam buku monograf bisa lebih global jangkauannya dan tersampaikan kepada masyarakat luas. Hasil penelitian yang memiliki dampak untuk perkembangan keilmuan akan jauh nampak implikasinya, sehingga akan lebih berkembang dan bermanfaat. Harapannya masyarakat luas bisa membaca, memahami, mempelajari, melanjutkan penelitian, dan mengambil manfaatnya.

Pustakawan merupakan profesi yang sangat lekat dengan sumber informasi elektronik dan tercetak, baik berupa buku, jurnal, literatur sekunder, serta jenis bacaan lainnya. Buku monograf merupakan buku yang isi tulisannya tentang satu subbidang ilmu tertentu yang spesifik. Monograf ditulis dari hasil penelitian tentang satu topik atau sejumlah topik tertentu yang relevan. Terbitan buku monograf tidak berseri. Orisinalitas dan temuan unsur kebaruan dalam sebuah penelitian (novelty) akan berkontribusi bagi masyarakat luas apabila dipublikasikan. Publikasi ilmiah hasil penelitian melalui artikel jurnal dan buku monograf diharapkan sebagai salah satu upaya sumbangsih keilmuan baik teoritis maupun dalam tataran praktis. 


\section{Daftar Pustaka}

Campbell, R., Ed Pentz, Borthwick, I. 2012. Academic and Professional Publishing. UK: Chandos Publishing.

Glogoff, S.J. and Bailey, M.J. 2019 (eBook). Monographic Works in

Sci-Tech Libraries. Dalam Monographs in Sci-Tech Libraries, ed.

Ellis Mount, https://doi.org/10.4324/9780429345531.

Https://isbn.perpusnas.go.id/.

Https://www.perpusnas.go.id/collections.php?lang=id\&id=Monogr af.

Https://www.perpusnas.go.id/organisasi.php?id=Kelompok\%20Pe ngolahan\%20Bahan\%20Pustaka\%20Monograf.

Https://www.researchgate.net/post/What_is_a_monoghraph_How _to_write_a_research_monograph.

Prytherch, Ray. 2016 (eBook). Harrod's Librarians' Glossary and Reference Book: A Directory of Over 10,200 Terms, Organizations, Projects and Acronyms in the Areas of Information Management, Library Science, Publishing and Archive Management. 10th edition. London: Routledge, https: / / doi.org/10.4324/9781315586243.

Research Monograph Definition. Tersedia di http: / / www.lisbdnet.com/research-monographs-definition/.

Thelwall, M. and Sud, P. 2014. No Citation Advantage for Monograph-Based Collaborations? Journal of Informetrics, 8 (1), p. 276-283.

What's in the Library: Books: Monographs. Tersedia di https://ocad.libguides.com/PrintBooks/Monographs. 